\title{
UNCERTAINTY AND ENVIRONMENTAL CHANGE
}

\section{Kutch and the Sundarbans as environmental histories of climate change}

\author{
Vinita Damodaran, Rohan D'Souza and Subir Dey
}

\section{Introduction}

This chapter explores understandings of uncertainty in South Asian environmental history scholarship. Environmental histories of South Asia have mostly evolved their plot lines around the theme of environmental change (Kumar, Damodaran and D'Souza 2011: 1-13). The overall mood in such narratives has often been described as being "declensionist" - that is, emphasising environmental decline and irretrievable ecological loss. While providing compelling insights and careful documentation of the environmental impacts brought on by European modernisation and western colonialism, these declensionist frameworks have been inadequate in their scrutiny of the pre-colonial period in South Asia (Grove, Damodaran and Sangwan 1998). In part, this striking limitation has been driven by the belief that pre-colonial societies aimed for ecological harmony, and this led them to strive for achieving relatively stable environments as they pursued resource prudence rather than profligacy (cf. D'Souza 2019).

Although a number of revisionist accounts have subsequently demolished the environmental stability thesis, recent anxieties about global warming have, understandably, pressed for another rethink over how South Asia's environmental pasts may be understood (Damodaran and D'Souza 2020). In particular, this includes the need to debate how understanding weather events and long-term climate trends can help us grasp how states and societies have responded to radical environmental uncertainties. Thus, we suggest a rethinking of the plausible environmental history plot lines and narratives for South Asia in the context of climate change and global warming and the possibility for de-centring the previous emphasis on environmental change and replacing it with the notion of "uncertainty". 
Uncertainty, as pointed out in the introduction to this volume, can be discussed in terms of its epistemic (knowledge-making) and ontological/aleatory (how Nature exists) dimensions (Chapter 1). And integral to uncertainty is what Sheila Jasanoff felicitously describes as the tensions between "global fact" and "local value" (Jasanoff 2010). While the global fact would refer to the high science of model building and the universal abstract protocols for collecting meteorological data (see Chapter 2), the local value, in Jasanoff's estimate, draws out how local communities experience and make sense of weather events and phenomena and the need to recover the local in our global regimes (Jasnoff and Martello, 2004). This is nicely illustrated through the empirical chapters in this volume (see Chapters 4-6). In effect, there is a friction between the qualitative that is borne by the everyday experience and the quantitative, which speaks for the abstract and distant assessment mainly by experts.

To illustrate and deepen our understanding of the notion of uncertainty as a framing device for writing environmental histories of South Asia, we focus in this essay on two dynamic environments in British India - the princely state of Kutch (in present-day Gujarat) and the Sundarbans (Bengal). For the colonial authorities, Kutch and the Sundarbans were overwhelmingly marked as being "marginal environments" and treated as being distinctly different from places and regions that were, in contrast, considered as the "environmental normal".

While marginal environments, especially for colonial officialdom, meant environments that were subject to frequent extreme weather and natural events such as droughts, floods, earthquakes and violent river behaviour, the "environmental normal" referred to the relatively productive, stable, predictable and revenueyielding zones (Heredia and Ratnagar 2003; Prasad 2003; Bhattacharya 2018; Saikia 2019). These contrasts between the "marginal" and the "normal" not only shaped different types of colonial administrative interventions and institutional capacities but, critically, there emerged as well a set of sociological and economic distinctions that were elaborated by the colonial authorities that helped further define these zones. Notably, the marginal was about subsistence communities that were characterised by mobility, vulnerability and regular environmental distress, while the normal comprised settled agrarian communities, revenuepaying cultivators and referred to spaces which saw markets and commerce flourish.

A second set of contrasts was over the notion of the environmental shock as opposed to that of gradualist environmental change. The regions of Kutch and the Sundarbans, we point out, were described and discussed within the administrative lexicon in terms of sudden and dramatic natural shocks such as earthquakes, cyclones or extreme floods, which not only resulted in the radical landscape change but could potentially cause the drastic erosion of livelihood possibilities and even the total abandonment of lands. In normal environments, on the other hand, environmental changes could be more gradualist and could be brought on by long-term activities such as steady forest clearances or even a persistent drought but without irreversible landscape change. 
The "marginal environments" (Kutch and the Sundarbans) having experienced limited interventions by the colonial state were substantially documented and studied between the 18th and 19th centuries. The town of Bhuj in the Kutch princely state had suffered from drought and scarcities of water while the Sundarbans remained vulnerable to recurrent extreme flooding, drastic landform erosion and ferocious cyclones. Both colonial and post-independent state initiatives in these two sites were instituted to turn them into "normal" and "secure" geographies (also see Chapters 4 and 5). Tracing the trajectory of such stabilising initiatives can help deepen our understandings of how uncertainty was experienced and discussed differently by layers of society, communities, experts and government officials across time periods, and how these translate into presentday response. In particular, we are keen to explore how the responses from communities, experts and the state or "below", "middle" and "above" differed in their approaches to viewing environmental change and the differing perspectives they provided for understanding how environments were represented and understood. The pastoralists in Kutch, for example, saw seasonal migration and mobility as critical adaptation strategies for their livelihoods, while in the normal zones, migration was mostly seen as a distress strategy or as desperate efforts to cope with an irregular or a one-off event (Mehta 2005). Similarly, communities in the Sundarbans remained agile to the moods of the rivers, as they hopped across islands and diaras or chars as part of their portfolio of livelihood strategies.

This essay, in effect, will seek to underline not only how the notion of the margin was, in several respects, framed as being a deviation to the normal and, therefore, caused British administrators to often misread local livelihoods, coping mechanisms and strategies aimed at harnessing uncertain environmental conditions. While the lack of environmental predictability meant a loss of control over territory and the populace for the colonial state, local knowledges, syncretic histories and pastoralist narratives can draw our attention to how certain kinds of social worlds could be more adept at handling environmental shocks. Below, we review the colonial archival record (from 1800 onwards) on what got described as calamitous events, natural catastrophes and environmental shocks in Kutch and the Sundarbans. The effort, in essence, is to read against the grain in order to explore and capture the varied conceptual tensions that ran through colonial efforts to frame marginal environments in terms of the normal through the lens of uncertainty.

\section{Discovering Kutch}

Kutch acquired political coherence from the late 12th century when the Jadeja Rajputs came to rule the tract. In 1819, the ruling house, accepted the suzerainty of the British East India Company (hereafter, EIC) with Captain James Macmurdo becoming the first political resident. Amongst the topographical peculiarities that Macmurdo quickly noted was the striking physical feature of a salty marshland of close to 10,000 square miles that comprised the Rann of Kutch, which alternated 
between being a seasonally dry sandy desert and a marshy inland lake with only small stretches of freshwater. ${ }^{1}$ He also recalled from memory in 1820 , the impact of the earthquake of 1819 that had ravaged the entire province. ${ }^{2}$ In 1824, James Burnes, a doctor, posted in Bhuj and his brother, Alexander Burnes, also wrote about Kutch. Their initial writings were focused mainly on the regional history of Kutch and were essentially a subtle justification for British rule. In 1829, James Burnes began to pen his observations of the land and people of Kutch.

The general appearance of Cutch is barren and uninteresting. Most of the villages are ruinous and dilapidated, bearing marks alike of the shocks of nature and the destructive powers of man. A few fields in their neighbourhood are cultivated, while the remainder of the country presents nothing to the view but a rocky and sandy waste, which in many places is scarcely relieved by a show of vegetation. Water is scarce, and often brackish; and although the population does not exceed three hundred and fifty thousand souls, the produce of the land under cultivation is insufficient for their support; so that Cutch, even in the best seasons, is dependent on Sinde for supplies of grain.

(James Burnes 1830a)

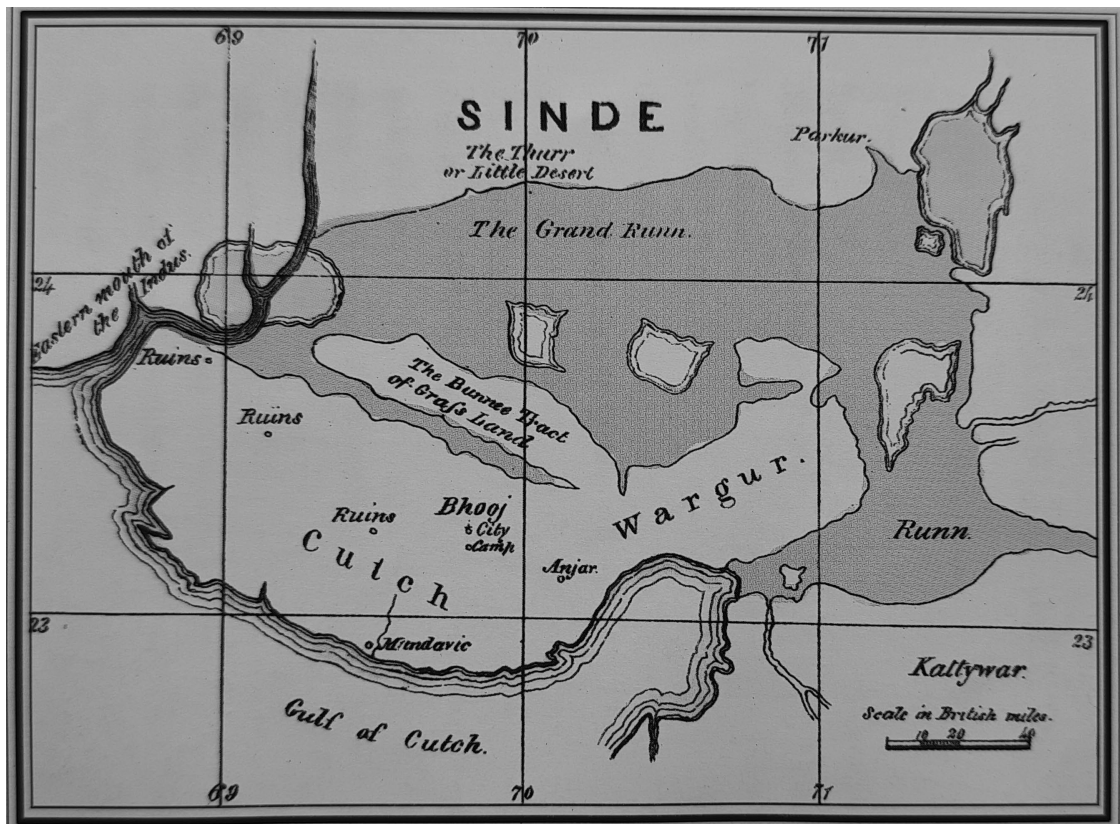

A SKETCH OF CUTCh, THE RUNN, AND COUNTRIES ADJACENT,

From Original Surveys by Capt ${ }^{2}$ A.Burnes, F.R.S, $8 c 0$,

FIGURE 3.1 A sketch of the history of Cutch (Burnes 1830). 
In addition to the fairly grim assessment of the resources and people, the brothers also advanced an understanding of the various castes, tribes, their customs, habits and social hierarchies ${ }^{3}$ and noted the unique Banni grasslands. ${ }^{4}$ In 1839, drawing upon the accounts of the Burnes, the writer Marianne Postans described Kutch as a "barbaric and primitive polity" that was marred by unfair and exploitative customs, which, she went on to conclude, could only be saved by the East India Company, who possessed "industrious sciences and the Christian faith". 5

It is only in the memoir of S.N. Raikes of 1854, that we finally note that Kutch is unhesitatingly described as a colonial administrative territory. ${ }^{6}$ Now geographically demarcated from the neighbouring province of Sindh, Kutch was shown to comprise an area of 6,500 square miles. As for the Rann and the Banni grasslands, it was believed that seismic changes had created these salty marshes by converting a large water body into a seasonally dry seabed - a fact borne out by the periodic discovery of sea fossils. ${ }^{7}$ There was also the building of the great embankment by Gholam Shah in 1770 on the Eastern branch of the Indus in Sinde (Sindh) and the building of canals for channelling the waters to the Kutch. ${ }^{8}$ The Grand Runn (Great Rann of Kutch) on its northern boundary was 9,000 square miles. Mostly a rocky and hilly terrain comprising three irregular hill ranges:

a Most northern range an irregular chain bordering the Runn, of rocks containing marine remains.

b Charwar range passing through the centre of the province connected to the former at a northwest point.

c Southern range connected to the centre of the Charwar range.

Apart from these ranges, Denodar was the highest peak among a cluster of irregular hills that contained volcanic material. Geologists had begun to take a keen interest in Kutch since an early period for this reason. Raikes reported that, in some seasons, generally when rain falls in July, the surface, particularly of the eastern portion of the Runn, would be stunningly covered with salt (see Figure 3.1). On one or two occasions, "I have observed the whole distance between Kutch and Parkur covered with salt as white as snow, which it exactly resembled. It had a most striking appearance". 9 The southern coast was fertile and all channels of water that flowed through the province were periodic and would swell during the rains, after which these would remain as detached pools of water. They were most prominent on the northern side of the city of Bhuj. ${ }^{10}$

The climate of Kutch was described as mild and agreeable compared to other parts of Bombay, the hot months being April and May. Along the coast these months were also found to be pleasant while the month of June could become cloudy before the preceding rains. Rains happened to be irregular and sometimes heavy and damaging to poorly designed housing. In 1850, it was reported that heavy rains fell claiming 50 inhabitants and led to the death of close to 20,000 cattle. After the heavy monsoon, fever and rheumatism were found to be common ailments in the province. It was observed that these ailments were particularly 
close to the Runn where the drying up of vegetation would release what was called "noxious vapours". The temperature would remain high until November and then winter would commence from December and last until March. The occurrence of cholera after the rains was, in fact, noted to be fairly regular. The average annual rainfall between 1848 and 1853 was 12 inches (59 centimetres), though even this amount could be very variable. ${ }^{11}$ As the political agent Reeves, in an 1878 despatch, observed:

Cutch is peculiarly situated as to rainfall being on the very edge of the South West Monsoon and getting a small and precarious rain, it is evident therefore that the sinking of numerous wells, whereby a permanent water supply is ensured, is of the first importance. ${ }^{12}$

The colonial narrative then was that, the Kutch was in dire need of improvements, especially through infrastructural interventions so as to be rendered into a productive and predictable landscape.

Despite the uncertain rainfall pattern, a variety of crops were grown that included coarse cereals such as bajra, muth, gowar, jowary, moong and even some amounts of wheat. Cash crops were also cultivated, such as castor oil and cotton. Cotton was exported to Bombay from the region, and in 1852, Kutch produced 75,000 maunds. Silk from Kutch found a substantial dedicated European clientele. ${ }^{13}$ Most Kutch dwellers were reported as being subsistence cultivators and did not own their lands. Proprietary titles to land and its jurisdiction known as Girasias were recognised by the British. This was, however, essentially confined to a much smaller constituency of members mostly from the Jharejah clan, who formed the Bhayyad or the brotherhood. These landholders reserved the right to levy taxes and fines on cultivation and goods in transit through their towns and villages. A small constituency of religious and charitable institutions held a certain portion of these villages and lands, for which they received grants from the Kutch durbar. These were known as Inamee and Khyratee. The British East India Company recorded and recognised these landholdings as part of their policy of non-intervention in the domain of religion.

In these colonial surveys, agrarian conditions were also described as being adverse, owing not only to the uncertain rainfall pattern but also to the high levies by local authorities. Additionally, duties across towns and villages that were collected by the landholders led to a concentration of surplus at one end of the social spectrum. During the mid-19th century, a trend became noticeable, wherein the durbar of the court kept acquiring more lands from the nobility. Lands in Kutch, consequently, increasingly began to be held directly by the court. ${ }^{14}$

All ports of Kutch were under the durbar and foreign goods were only allowed to be imported through them. Sea customs were levied on all goods and the durbar and landholders of the nobility levied transit duties on merchandise in whichever direction they moved. By virtue of the treaty with the Kutch durbar, it is important to note that Company goods were exempted from the sea customs. ${ }^{15}$ 
Known for their maritime success, the Kutchis were intrepid seafarers and many fortunes were made from oceanic trade. Port towns like Lakhpat, Jakhau, Mandvi and Mundra retain even today, albeit to differing degrees, reminders of an earlier prosperity. While there have been studies focused on the seafaring traditions of Kutch that supported trade and migration, the overland migration that occurred across the Rann into Sindh and thence to Central Asia and beyond historically has been less studied (Simpson 2003).

\section{Pastoralism and weather uncertainties}

The Rann turned marshy during periods of rainfall and breaks into a collection of raised islands, where habitation becomes possible. These islands or gauchar bets, which were also regarded as common lands, moreover, were overrun by a vast carpet of lush nutritious grasses. The Banni grasslands often find mention as being one of the largest bets in the Rann and colonial accounts describe it as attracting a number of pastoral groups with their cattle, who were even able to enjoy a better lifestyle than the agriculturalists (Williams 1981: 222).

The colonial records, it should be noted do not refer to the pastoralists of Kutch in occupational terms, rather they were listed as nomadic tribes. While they did not have proprietary rights to the Banni, which was held by the Durbar, they had unlimited grazing rights. What they were taxed for was not grazing rights but their trade in butter. There were, moreover, strict grazing regulations for sheep and goats who were prevented from grazing in the earlier period which helped preserve the grassland resources for camels and cows (Ibrahim 2004). While recording land titles and ownership, Arthur Malet in 1842 remarked that in the district of Banni an estimated 100,000 cattle were tended to in this tract and five kutchi kories (local currency) ${ }^{16}$ were levied on every maund of clarified butter that was produced. In that very year, the revenue that the durbar received from Banni was 70,000 kutchi kories. It is unclear if this revenue was accrued through levies on butter or some other means as well. ${ }^{17}$ The Banni, moreover, was vulnerable to pillage from seafaring pirates and also suffered cattle theft. The British East India Company thus had to secure the property from such raids even as vulnerabilities from extreme weather events and famine regularly occurred. ${ }^{18}$ In the 1880 s, one colonial report on the Banni tellingly described it as follows:

'[...] is all apt to be covered with water in times of high flood. The whole is scantily covered with coarse grass and babul trees, and supports large herds of buffaloes and other cattle, for whose use some wells and ponds have been dug. The herdsmen live in clusters of beehive shaped grass huts, and under the orders of their holy men use no sleeping cots and light no lamps after dark.' On the pastoralists they noted that the 'Rabaris 13,371 strong, also called Bhopas because many of them serve in Mata temples, a wandering tribe of shepherds are generally found in the Banni and other rich pasture lands of north Cutch'. 19 
One also gets the idea of the recalcitrant frontier in the colonial archive. "The Muhammadan herdsmen in the Banni (a tract of grasslands extending along the edge of the northern Rann) are reckoned fierce and unsettled" noted Macmurdo in 1820. When caravans laden with goods - rice, dates, silks and cloths - would cross the Rann during the trading season between mid-September and midJune, their safety was not easily guaranteed. ${ }^{20}$ Tribes along the way had to be mollified with payments to prevent the looting of goods.

The colonial state, perhaps not unsurprisingly, as part of their efforts to pacify and settle what increasingly appeared to them as a marginal, uncertain and volatile zone sought to transform the pastoralists into a sedentary community that could be more legible to their taxation regimes. Amongst the first initiatives was to enclose the commons and village forests. Local ecologies had various local terms identifying their importance to the common people: common lands which were termed as gauchars bets; islands in desert tracts termed as Pung, Aaliya and Nada; Grasslands like Banni, Kaddr, Lakhpat and Vadhiya; and Forests like Gir, Bardas, Aalech, Vidis and Rakhal. Pastoralism was adapted to the environment with mobility being key, with groups moving between Sindh and Kutch taking their herds where they would find fodder. The livestock included three native breeds of Oxon: Bagadia and Bharbads reared by Rabaris and the Banniai referring to Muslim herdsmen in the Banni. During the several famine episodes that were noted in the region, migration was the main response of local pastoralists. In 1823, it was recorded that there was a migration of people and death of cattle due to famine. In 1860, severe scarcity of provisions led to heavy migration to Sindh, Kathiawar and Bombay, and the cattle were even driven to Gujarat.

Colonial sources have recorded close to 102 episodes of what they would consider calamitous events in Kutch through the course of the 19th century. Aside from the earthquake of 1819, the remaining 101 instances counted relate to extreme weather events. The list mentions 48 years as being marred by poor or untimely rainfall leading to crop failure with some years tipping into becoming famines. In the remaining 52 years, though there were a range of weather uncertainties such as unintended showers, unexpected timings for rain and even shock floods that brought about scarcities in fodder and grass and especially increased the prices of food grains. Each event produced consequences for livelihood and economy, which lingered on for years. A closer look in Table 3.1 details these events.

In the first decade, barring the two years of 1803 and 1804, the decade witnessed predictable weather events. However, the next decade was a trend in reverse, barring 1814 and 1818, one or more calamitous events occurred. This decade began with "pestilence resulting in crop failure" and famine followed by an epidemic of plague in 1812. In 1813, the epidemic continued and was accompanied by famine. While the situation began to marginally improve in 1814, in May 1815, the cropped fields witnessed heavy rain and rats robbed the cultivators clean. The epidemic of plague reappeared in 1816 and continued in 1817. While 1818 provided some succour, June 1819 witnessed an earthquake, followed by a heavy monsoon that destroyed crops. Untimely, rain and poor 
TABLE 3.1 Table showing climate-related events in 19th century Kutch

\begin{tabular}{llllll}
\hline $\begin{array}{l}\text { Decades of the } \\
\text { 19th Century }\end{array}$ & Famines & $\begin{array}{l}\text { Crop } \\
\text { Failure }\end{array}$ & Pestilence & Epidemic & $\begin{array}{l}\text { Rainfall } \\
\text { Failure }\end{array}$ \\
\hline $1800-1810$ & 1 & 1 & 1 & 2 & 2 \\
$1811-1820$ & 3 & 4 & 2 & 5 & 5 \\
$1821-1830$ & 1 & 1 & 1 & 0 & 2 \\
$1831-1840$ & 0 & 1 & 1 & 0 & 1 \\
$1841-1850$ & 0 & 2 & 0 & 0 & 3 \\
$1851-1860$ & 0 & 1 & 0 & 0 & 1 \\
$1861-1870$ & 0 & 4 & 2 & 1 & 5 \\
$1871-1880$ & 0 & 3 & 1 & 3 & 5 \\
$1881-1890$ & 0 & 0 & 0 & 0 & 0 \\
$1891-1900$ & 2 & 0 & 0 & 5 & 4 \\
\hline
\end{tabular}

Source: Authors' own using information from the Gazetteer of Bombay Presidency, Volume V 1880.

harvests closed the decade in 1820 and the period 1821-1830 had seven years that did not witness any widespread calamitous event.

The decade of 1831-1840 was comparatively free in terms of calamities, with only three years of adverse rainfall leading to poor harvest and crop failure. The following decade of 1841-1850 appears to be balanced with five years of primarily poor rainfall leading to crop failure but with two earthquakes in 1844 and 1845 noted as severe but without any additional details. The following decade had only two years known to have adverse rainfall and crop failure. This was followed by the decade of 1861-1870 in which frequencies of calamitous events were similar to the decade of 1811-1820. This state of affairs was only marginally reduced in the following decade of 1871-1880. In this decade, seven years saw active calamities which also included plague in cattle and animals in 1872 and 1878 that had serious consequences on livelihoods. The count of these events in the last decade of the 19th century stands at nine active years of climate events and one clear year. The earthquake episodes from 1892 to 1895 did not seem to have any drastic impact enough to have entered the colonial records. The plague epidemic outbreak between 1896 and 1900, however, caused huge casualties and was accompanied by untimely rains and poor harvests (see Table 3.1). ${ }^{21}$

\section{State and people: the twain never meets}

A close study of the pattern of responses, from "above" and "below" that these frequently occurring extreme weather events evoked, shows that people and the state responded in different and often contrasting ways. The colonial state after some initial hesitation began to reconcile itself to the idea of having to settle for a mixed bag of good and bad years. In particular, the administration had to ensure that their revenue collections had to be correctly indexed to the actual abilities 
of the local populace to pay after an extreme event. In 1842, when Arthur Malet, the political agent at Kutch surveyed and documented the towns and villages and their ownership, the aggregate of revenue including all items and of all revenue receiving entities was estimated at 62,95,745 Kutchi Koris. Malet remarked that in a good year at least 64 lakhs Kutchi Koris of revenue was realised and then proceeded to estimate the most probable trend of revenue realisation under three additional categories, namely, the following:

a Sookal which meant a very good year.

b Dookal which meant a year of famine.

c Kurwara which meant a year of when one fall of rainfall has failed.

Against each kind of year, there was a proportionate adjustment in the scale of revenue realisation. ${ }^{22}$ Nonetheless, prices for necessities often escalated in difficult years. A report in 1872 on the previous year's harvest, notes:

[...] the monsoon has been unfavourable even for Kutch, where a precarious rainfall is the rule. The total number of inches was 3 inches and 47 centimetres, of which no less than 3 inches and 4 centimetres were registered during the first week in May, a most untimely fall. The consequences has been diminished harvests throughout the country, and high prices for grain, grass and the necessaries of life, with much distress. ${ }^{23}$

Locusts sometimes could ruin a good harvest. In 1872, the year which recorded a good harvest owing to

seasonable and copious rain during last monsoon throughout the province, after the previous year's unfavourable and scanty fall, has relieved much of the distress that prevailed [...] in consequence of the appearance of locusts when the crops were standing, and a good deal of damage was done in most of the districts thereby. ${ }^{24}$

One of the main responses of the populace to rain deficiency and such kinds of distress was to resort to strategic migration as noted in 1876:

There was a deficiency of rain all over the Province, the average being only 7 inch 21 centimetres, or about half the usual supply. The three pergannas bordering on Sind were the greatest sufferers. The crops in them entirely failed, and a large portion of the population emigrated. The food supplies of the country were thus relieved. But severe scarcity has prevailed everywhere, and the water and forage supplies are dangerously low. ${ }^{25}$

The transitory nature of such migration was noted, in 1891, for example, it was reported that in Bhuj owing to poor rainfall "the grass preserves of the Darbar as 
well as the common pasture lands of the villages" failed to meet the demands of the domestic animals and immediately spurred the pastoralists to seek pastures elsewhere. ${ }^{26}$ Almost a year later, however, the pastoralists who had migrated "drew back to Cutch several herds of cattle which had left the province for want thereof in the previous year". 27

While temporary distress migration seemed part of the rhythm for coping with the vagaries and uncertainties of the inhabitants of Kutch, the colonial administration increasingly saw well irrigation as the solution to preventing mobility:

Scarcity and rain and danger of famine in Cutch are not unfrequent, and special precautions are necessary, against the distress arising there from. Well irrigation has been long considered to afford a sure, certain and suitable remedy, especially in this Province. The Council of Regency who conducted the affairs of the principality during the minority of His Highness the Rao recognised the necessity of increasing well irrigation as much as possible; since his accession to full powers of State, his Highness the Rao has also spared no pains in increasing wells and encouraging improved cultivation of land. ${ }^{28}$

Interestingly, since in most official reports the cause of famine in Kutch was seen to be a result of multiple years of bad weather, the administration linked migration not to pastoral rhythms and coping strategies but exclusively to rainfall deficit and weather uncertainty. Well irrigation, consequently, became the widely accepted official response which as a "[...] measure will not only keep compact and steady the subjects of the State in those parts, but will also bring to their doors a certain supply of water on which they can depend". ${ }^{29}$ That is, the lack of cultivation in Kutch was seen as a natural calamity. The pursuit of a robust policy for sedentarisation, thus, also followed from the need to prevent migration and mobility.

The improvement of agricultural resources of the country was highlighted as being necessary and involved the administration in trying to ensure that there was an "abundance of manure, good cultivation and plentiful supply of water". 30 The State attempted to partially assist the cultivating classes by advancing money and granting remissions and also giving Takavi (loans) and grants-in-aid. ${ }^{31}$ In effect, by the end of the 19th century, a set of interventions for the sedentarisation of the populace improving well irrigation, revoking transit duties, relief work in the form of construction and taking over wastelands was considered to be the main response of the colonial state, which stood in striking contrast to that of the local populace that sought to develop and orient their coping strategies around temporary and seasonal migration as they historically had always done. As the exactions of the colonial state intensified forcing sedentarisation on pastoralists, further changes in land use and boundary changes following the partition of India limited the range of responses to local climate events among these communities 
leaving them more vulnerable to uncertainty and climate change (Mehta and Srivastava 2019; also see Chapter 4 for postcolonial interventions in Kutch). We now turn to a similar examination of uncertainty in historical perspective in the Sundarbans.

\section{Sundarbans' migratory rivers and mobile people}

The Sundarbans comprises the most volatile deltaic portions that is borne out of the confluence of the massive Ganga, Brahmaputra and Meghna river systems. The region which overlaps both Bangladesh and India, has a unique ecology that is hedged in by mangroves, littered with mudflats and cut into innumerable islands by streams and channels. Given the fact that the Sundarbans is a highly unstable landscape that is recurrently moulded by tidal actions, floods and regular marine erosion, the early East India Company (EIC) officials, unsurprisingly, were overawed upon gaining possession of the territory in the final decades of the 18th century (see Figure 3.2).

Upon seizing the right to assess and collect revenue in the Sundarbans in 1764, the EIC officials first set their sights instead on containing the threats from the Magh, who were variously described as pirates and accused of plundering ships and carrying away populations for the slave trade in the Arakans. Apart from securing the routes of commerce that carried out through the many channels between the river Meghna and Hooghly, the Company also aimed to expand

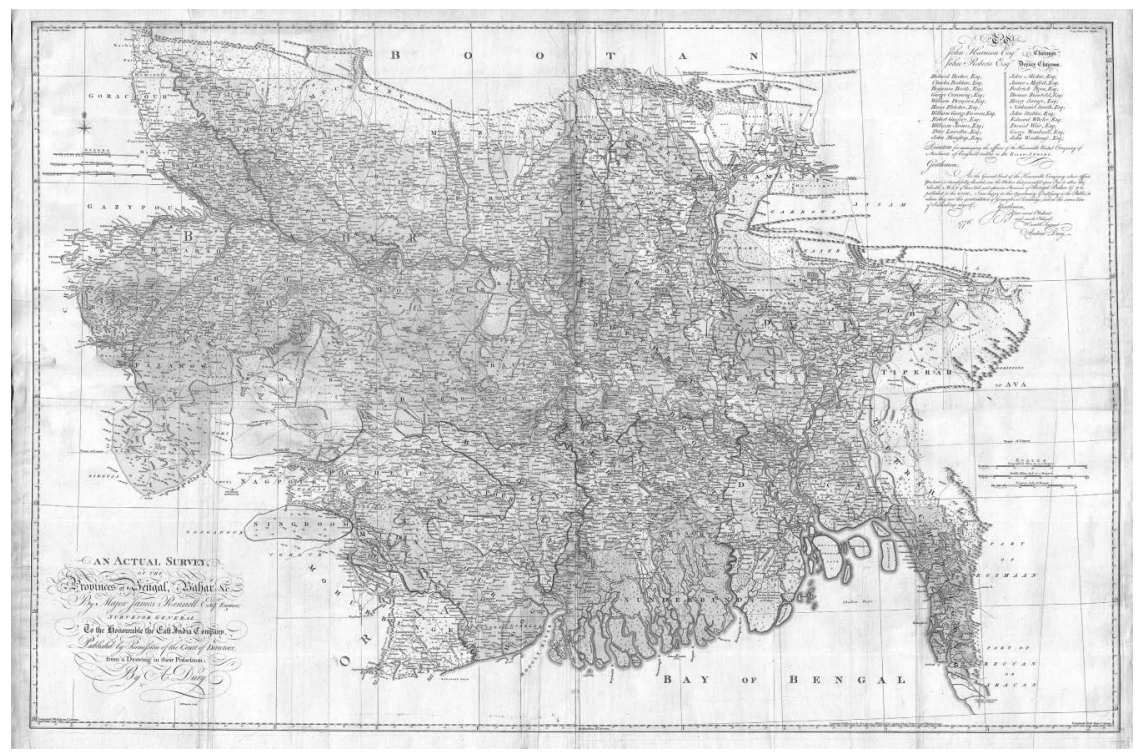

FIGURE 3.2 Early Survey and Mapping of Sundarbans 1794.

Source: Map of Bengal, Bahar \& C. prepared by Major James Rennell, Engineer and Surveyor of East India Company, published on 12th May, 1794. 
cultivation in the lower portion of the delta to prevent raiders from taking cover in the Sundarbans forests (Chatterjee and Sarkar 2010).

Colonial administrators amidst difficult efforts to settle the volatile deltaic tracts, however, were led to systematically document the forest and vegetation cover for close to 150 years. The importance of fisheries was also recognised earlier on when the Sundarbans were acknowledged as possessing the "most valuable of the estuarine fisheries in Bengal", with the numerous waterways being full of fish. But the "deterioration" of several channels in later years, it was noted, had caused the water to turn brackish in several places such that "carp have already deserted them". 32

Three aspects of the Sundarbans, however, came to define the colonial documentary record in the region. First were the complications brought on by efforts to build and maintain embankments to secure the region from the regular devastations of the annual floods, an intractable issue that persists to date (see Chapter 5). Second were the tensions between ensuring forest conservation for timber, while, at the same time, encouraging the agrarian expansion and settlement in the deltaic tracts. The third involved the colonial anxieties bought on by cyclonic storms and their potential devastations.

\section{Embankment construction}

For the EIC, the project of building embankments and maintaining them proved to be a conflicted intervention that preoccupied colonial officials, landlords and cultivators throughout. From 1783 onwards, officials began to farm out schemes for reclaiming lands from forests and marshy terrain. The first attempt in this direction was by Mr. Tilman Henckell. ${ }^{33}$ Apart from reclaiming forest lands for cultivation, Henckell intended to extend the agrarian frontier so as to deal with a potential situation of famine. The famine of the 1770 s was still fresh in public memory as it had allegedly killed ten million people.

Initially, embankments in order to protect the reclaimed lots were undertaken by landlords and the cost of repairs was reimbursed by the Company. In 1785, the government resumed the pulbandi (embankment) charges and undertook maintenance on their own. However, in 1791, it decided to place the burden of the cost of repairs on landlords again and, not unexpectedly, faced considerable resistance from these groups. The landlords stated that if monetary assistance was not given by the Company, all losses in revenue incurred due to floods should be pardoned by the Company. As a result of this argument, this measure was withdrawn. The British government then farmed out the maintenance of embankments to Salt Agents who did so until 1803 when an Embankment Committee was formed. This Embankment Committee, however, failed to function properly, and in 1814, the government was obliged to rebuild embankments at their own expense. In 1816, a Sundarbans Commission was formed that operated till 1821. In 1819, the government asked the landlords to estimate and undertake repairs of the embankments under an embankments 
superintendent. In 1834, the government withdrew monetary support for this purpose but owing to protests and losses, resumed maintaining the embankments through its Public Works Department. The maintenance of embankments and their impacts on the environment, however, continued to draw debate and dissension throughout the colonial period. ${ }^{34}$

\section{Forestry against Reclamation}

Reclaiming the forest was part of the push by the Revenue Department for bringing tracts under cultivation. However, the period from 1870 to 1879, when new rules for the reclamation of wastelands in the Sundarbans were issued, a number of disputes erupted over the sale and lease of forest land. In part, this was because the forest department considered forests more useful than rice cultivation. ${ }^{35}$

The policy of Sir Richard Temple, the then Lieutenant Governor, was a case in point for he argued against any need for reclamation as the resources grown in the Sundarbans already were more valuable than creating more paddy fields. His policy resulted in the creation of the Reserved and Protected Forest in Jessore (Khulna) and the 24 Parganas. Temple chose to record his views about the importance of forest resources:

Western Bengal is supplied partly from the Sunderbuns and partly from the high lands to its west. The southern districts of Central Bengal draw ample supplies of cheap wood from the Sunderbuns. In the city of Calcutta firewood is probably cheaper than in any large town of India; a short system of rivers and canals brings the products of the Sunderbuns to several parts of Calcutta and its environs. To the northern districts of Central Bengal, bamboos and timber are brought by river from the sub-Himalayan forests. Eastern Bengal is supplied by water from the Sunderbuns, from the frontier jungles, and from occasional private forests scattered over the country. ${ }^{36}$

But the impetus for cultivation continued and 3,305 acres were transferred to the civil authorities to be leased for cultivation. ${ }^{37}$ The region soon became quite profitable and it was noted that

It will be seen that there is a large and increasing surplus, so that the general result is satisfactory. The profit is very great in the Sunderbuns Division, from which Calcutta is supplied with fuel, and also the important sugar and other works scattered through Khoolna and Jessore.

It was further reported that

After sal (Shorea robusta) we have to notice sundri (Heritiera littoralis), the important produce of the Sundarbans forests, which serves to construct most of the native river craft met with on the Hooghly and adjacent 
channels. In the water-divided country of the 24-Parganas, Khulna, Backergunge, Noakhali, and neighbouring districts, the rivers and creeks to a great extent take the place of roads, and boats the, place of carts, so that the value of the Government forests of the Sundarbans to the country at large is immense. Again, all the firewood used in Calcutta is brought from these same forests. The financial results were reported by the Sundarbans Division as especially satisfactory. Besides expending only 28 per cent, of its receipts it furnishes no less than 45 per cent, of the revenue of the whole circle. The regularising of the work and the introduction of the monopoly sale system have so improved matters that the period of its administrative uncertainty may be considered to be a thing of the past. The revenue during the year increased by Rs. $51,000 .^{38}$

It was further reported that the reclaimed tract to the north was entirely devoted to rice cultivation and winter rice of a fine quality was grown there; sugarcane and areca-palms were also cultivated in the tracts lying in Khulna and Backergunge districts. The methods of cultivation included the following:

when land is cleared, a bandh or dike is erected round it to keep out the salt water and after two years the land becomes fit for cultivation; in normal years excellent crops are obtained, the out-turn being usually about 20 maunds of rice per acre. ${ }^{39}$

The debate on forests, however, remained very intense and often bitter. It was reported that by 1877 the limits of the forest reserve had been fixed, even as a considerable area of wasteland, the revenue administration believed had been excluded and was still available for reclamation, ${ }^{40}$ causing them to aggressively declaim in a note that as late as 1853 the

Government had declared that the paramount object of its policy in the Sundarbans was the speedy reclamation of the forest in order to improve the health of the neighbourhood of Calcutta and to deprive wild animals, smugglers and pirates of the shelter afforded by the jungle: the improvement of the revenue was of secondary and altogether subordinate importance. ${ }^{41}$

The history of forest demarcation, the debates on reclamation and cultivation and the responses of the Forest Department were to prove vital in partially protecting the region against cyclones. Although the Sundarbans forest was declared government property in 1817, it was not declared a protected forest area until 1878. At this time, 4,856 square kilometres in the south-eastern part of the Sundarbans was officially preserved by British authorities. This was an important victory not only for the Indian forest department but also for the deltaic stretch as well as these reserved and protected forests proved important in giving protection for cyclones and floods. 
From the brief account "above", one can gauge the slow pace at which the Sundarbans was brought within the domain of the colonial administration and the competing claims of the forest and revenue departments. During the middle of the 19th century, there were many proposals made that sought to undertake reclamation and settlement at a mega scale through mobilising big capital and labour. In January 1865, Ferdinand Schiller presented one such proposal of reclaiming all the remaining "wastelands" of the Sundarbans that, as per his estimation, was about close to one million acres, which included tracts that were yet to be surveyed. He proposed to introduce settlers from China, Madras and other parts of the coast of India and also encourage the immigration of free labour from Zanzibar on as large a scale as possible. He proposed to grow cotton on these tracts. Ferdinand summed up his rationale thus and is indicative of how gigantic the scale of his enterprise was being envisioned:

The object of my application is to provide for the speedy cultivation of the large tract of fertile country stretching to the Eastward between Canning and the River Megna. This would not only give a great additional impetus to the trade of Bengal, but materially improve the sanitary condition of both Canning and Calcutta. To accomplish this two things are required: money and population. The latter I could not hope to obtain by the mere withdrawal of excess population from other parts of India, as it is well known that India in many parts is suffering from great want of labor; and although it may seem strange that with such facts before us emigration to other distant Colonies is actually facilitated, yet I look upon this as a mere consequence of free trade and I do not complain of it as a grievance, claiming on the other hand the right and privilege to introduce the necessary labor for the accomplishment of my scheme from such parts of the world as may appear desirable. The first country I should direct my attention to is China, where the peaceful agricultural classes have long been suffering from the consequences of Civil wars, and where, I know a good class of laborers with their families could be obtained under the altered conditions of that country. In settling Chinese we should introduce a superior race, a race which would soon rise into a trading population and keep up by its own spontaneous action a constant and regular stream of immigration. With these men, we should have to deal to suit their peculiarities, and each family would probably have to be started as small farmers at once, being under bond to the Company for the refund of their passage money and paying such rents for the land they occupy as may be considered fair and equitable. San Francisco, the Straits, and many Islands in the Indian Archipelago have thus been successfully populated. Another class of labor I should propose to draw from various parts of the African Coast. With these men a different system would probably have to be adopted. In addition, we will, of course, obtain cultivators from other parts of India. Special Acts of Legislation will have to be passed for the introduction of what may be 
termed foreign labour. In entering on this cultivation we should have to leave certain belts of jungle, say 10 miles inland facing the sea, untouched, partly with the view of protecting the inner cultivation against the storms in the Bay of Bengal, partly in order to preserve the supply of fuel for the surrounding population; but many of the outer grants would have to be protected by good bunds, similar to those which prevent the sea from washing over some of the richest portions of Holland. ${ }^{42}$

What Schiller was proposing was not within the rules of settlements and perhaps owing to a miscommunication the proposal remained shelved and led many investors to withdraw from the venture. However, something much more dramatic happened that put an end to any real prospects of such a proposal; this was the total destruction of Port Canning in a cyclone in 1867 to which we will now turn in the context of the cyclone history of the region.

\section{Cyclones, uncertainty and devastation}

The Sundarbans, for the early officials of the EIC, appeared almost deserted and it took them a while to connect the relative lack of habitation and settlement to the devastating impacts of the 1737 cyclone, which were still lingering:

There remain yet to be considered the effects of a cyclone and its storm waves. This occurred in Calcutta in 1737, cyclone, "when a wave 40 feet higher than usual, came up. Such would have been sufficient to produce an almost total loss of life in the Sundarbans and its consequent abandonment."

It was debated in colonial sources whether it is the constant invasions by Portuguese and Mug (sea pirates) that have created this condition of abandonment or whether it was the harsh environment of the Sundarbans and the argument was settled in favour of the latter. The extent of revenue collection in the past was also debated. It is believed that at one time the Sundarbans was far more extensively inhabited and cultivated than at the present; and possibly this may have been due to the fact that the shifting of the main stream of the Ganges from the Bhagirathi to the Padma, by diminishing the supply of fresh water from the north, rendered the tract less fit for human habitation. ${ }^{43}$

There is a strong indication that in the times of the Mughals (1526-1857), the Sundarbans was, indeed, inhabited. A cyclone of 1585, nonetheless, finds mention in the writings of Abul Fazl, where he notes that

The Sarkar, or district, of Bagla, extends along the seacoast. The fort of the Sarkar is surrounded by a forest. From new moon to full moon, the waves of the sea rise higher and higher; from the fifteenth to the last day of the moon, they gradually decrease. In the 29 th year of the present era 
(A. D. 1585), one afternoon, an immense wave set the whole district under water. The chief of the place was at a feast; he managed to get hold of a boat, whilst his son Paramanand, with a few others climbed up a Hindu temple. Some merchants got on a Tâlâr ${ }^{\star}$ For nearly five hours the waves remained agitated; the lightning and the wind were terrible; houses and ships were destroyed; only the Hindu temple and the Tâlâr escaped. About two hundred thousand souls perished in this hurricane. ${ }^{44}$

The cyclone of 1585 did not result in the depopulation of the Sundarbans because Abul Fazl, 11 years later, in 1596, mentions four towns as belonging to the Sarkar of Bagla, viz., Isma'ilpur, commonly called Baglachinj, Srirampur, Shahzadahpur and Adilpur. These four places must have been of some importance because the district then paid a revenue of nearly 70 lakhs of dams, that is, nearly 180,000 lis., and was besides liable to furnish 320 elephants and 15,000 zamindari troops. ${ }^{45}$ Earlier debilitating cyclones, therefore, had not deterred people from settling in the area as one report noted the frequency of storms and the consequent suffering:

The colonies of settlers in Sundarbans are specially exposed to the fury of such storms. Their houses and their fields are only a foot or two above high-water mark and when the cyclone wave pours up the great streams of the Poseur and Haringhata, and from them spreads over the country, the inundation works cruel havoc among the low-lying isolated villages. The grain in their fields is spoiled their houses are torn away and all their stores are lost their cattle are carried away and drowned; and they themselves are reduced to extreme shifts to save their own lives. ${ }^{46}$

The frequency of cyclones was also apparent from the literature. In October 1895, which swept over both the Bagherhat and Satkhira subdivisions

On 16 May 1869, a cyclone destroyed 250 lives in Morrellganj alone and caused an immense loss of property. ${ }^{47}$ It was reported in 1870 that the average annual rainfall varied from about 82 inches in the west to over 200 inches in the east. Cyclones and storm waves occurred from time to time. The worst of the calamities of this nature was in 1870 when a great part of the Backergunge and the adjoining districts was submerged, the depth of water in some places being over ten feet.

In the night of 31 October and 1 November 1876, another report noted that the most terrible cyclone and storm wave had been experienced since 1822 . The greatest havoc was confined to Chittagong and the estuary of the Meghna and accordingly the Bakarganj portion of the Sundarbans suffered severely; in Galachipa thana, no less than 10th of the population was estimated to have been drowned. The calamity was described in detail by Sir Richard Temple, Lieutenant Governor of Bengal, who visited the affected area immediately after the occurrence and a vivid account is contained in the Gazetteer of the Bakarganj 
District published in 1918. Crops and cattle were destroyed far and wide, and the immediate effect of the storm, so far as it effects this history, was the relapse of a vast area of the Sundarbans in Bakarganj to jungle. ${ }^{48}$ The secondary effect of the cyclone was an enquiry into the possibility of erecting refuges to protect from loss of life in case of similar calamities. This cyclone heavily impacted land leases as several lands were submerged by the storm. Importantly, it was also reported that

Khulna was affected only to a small extent by the terrible cyclone and storm wave of 1876 but its immunity was largely due to the protection afforded by the large area of forest and to the fact that no reclamation had been undertaken in the danger zone with the exception of lots 1 to 6 (Khaulia-Barisal) on the Haringhata estuary. ${ }^{49}$

In contrast to Bakarganj being severely impacted by the 1876 cyclone, it appears that the creation of more reserved forests in Khulna protected the district from the impact of the cyclone. Clearly, here the transformative potential of forests to protect against natural disasters was widely commented on. ${ }^{50}$ The rich state of the forests was commented on frequently:

It appeared to be clear, both from the look of the forests and from the statements of the wood-cutters, that the Sunderbuns forests reproduced themselves in ten to twenty years. One-twentieth of the forest area would yield about 700,000 tons of firewood and petty timber per annum, or more than would supply all the requirements of Calcutta and the Delta districts, and therefore the Sunderbuns forest might be trusted 'to supply the wants of the country without any interference'. 51

Forests not only provided protection from cyclone but the colonial reports also give details about people livelihoods and how they were linked to the forest. Woodcutting and fishing were recorded as being part of people's livelihoods though the dangers of tiger attacks continued to be high. In 1908 it reported the practice of the woodcutters:

These brutes, who will swim broad streams in search of prey, are justly dreaded by those whose business takes them into the forests. No woodcutter will go there to cut wood unless accompanied by a fakir who is supposed to have power over tigers and other wild animals. Before commencing work, the fakir assembles all the woodcutters of his party, clears a space at the edge of the forest and erects a number of tent-like huts, in which he places images of various deities, to which offerings are made. When this has been done, the allotment is considered free of tigers; and each woodcutter, before commencing work makes an offering to the jungle deities, by which act he is supposed to have gained a right to their protection. In the event 
of any of the party being carried off by a tiger, the fakir decamps and the woodcutters place flags at the most prominent comers of the allotment to warn off others. ${ }^{52}$

Yet the number of tiger deaths continued and they themselves came under attack. In 1906, the number of persons reported to have been killed by tigers in the Sundarbans was 60 against 79 in the previous year with the number of tigers killed during the year being 35. In 1914, the number of persons reported to have been killed by tigers in the Sundarbans was 79 against 81 in the previous year and the number of tigers killed during the year was 39. In 1916, the number of persons reported to have been killed by tigers in the Sundarbans was 19 against 60 in the previous year and 86, the average of past five years. it was noted that "There was an appreciable increase in the number of deaths by tigers, the total figure being 81 in 1917 against 55 in 1916". 53 The number of tigers killed increased from 110 in 1916 to 123 in 1917. In 1919, the number of deaths caused by tigers showed a decrease, the number being 28 against 60 in the preceding year and the number of tigers killed decreased from 104 in 1918 to 86 in 1919. Tigers were clearly a force to be reckoned with in this period and were actively killed by the settlers. ${ }^{54}$

Two devastating cyclones hit the centre of the Sundarbans and Calcutta in the latter half of the 19th century. This was a period when colonial weather data and collecting cyclones had made a big step forward. It was realised by colonial scientists that climate and weather are complex phenomenon and vary through time and geographically. The colonial scientific network allowed for the possibility to collect useful data through lots of data points and an information flow network that spanned Australia, India and oceanic islands such as Mauritius and St. Helena. The "Monsoon" coined from Arabic mawsin (a season) was key to understanding world climate and, therefore, the Indian peninsula became key to understanding world climate. Between 1700 and 1924, main features of world climate discovered by Indian civil servants and officials, who were mostly Scots, Germans\& Bengali. ${ }^{55}$ They included the remarkable Henry Piddington who wrote the Law of storms and coined the word cyclone in 1848. By 1852, there were 123 weather stations in India with the Centre of Calculation being in Calcutta. The journal, Asiatic Researches published the data which included a detailed study of cyclones. ${ }^{56}$

The 1864 storm had a width of 100 miles and was proceeding at a speed of 10-17 miles per hour. The greatest damage on land was from a 15 -foot storm surge. It was reported that at the end of the cyclone, 48,000 people were declared dead in Calcutta and environs about $1 / 3$ of the population including those who died in the aftermath due to death by cholera. The official report of the 1864 cyclone by Henry Blanford is a biography of the cyclone. ${ }^{57}$ The storm chart of the Bay of Bengal drawn up by Henry Piddington showed that the majority of the cyclones, the tracks of which are there laid down, proceeded from a line running from south to north by the Nicobars, Andamans and the islands of the 
Arracan coast, following the westward side of the mountain axis, which, in part, submerged and a prolongation of the Sunda Islands.

Of these storms, several appear to have originated in the neighbourhood of the Andamans. The force of the cyclone was intensified by the formation of a tidal bore in the Hoogly breaching dykes in many places and leaving the interior flooded. ${ }^{58}$

Local ships like the Alexander, Clarance and the Comet gave details of the storm. On the impact of the 1864 cyclone itself, contemporary reports noted several details. Babu Chatterjee noted that in Tamluk Bazaar in Midnapur, the storm waves rose and the water stood 12 feet "above" the roadway and of the 1,400 houses and huts only 27 were left standing. ${ }^{59}$ In Calcutta, heavy winds and the fall of barometric pressure to 29.7 accompanied the storm on the 6th of October felling several trees in Chowrangee.

Wherever there were trees, they were either uprooted and fell, carrying with them in many cases walls, railings and buildings, or their branches were snapped off like reeds and hurried away with the wind. Carriages and pulkees were upset and strewed the roads, mingled with the debris of roofs, verandahs, gates and fallen trees; corrugated iron roofings were torn, doubled upand blown away like sheets of paper. ${ }^{60}$

The cyclone showed the differential impact on the rich and poor. In Calcutta alone, 102 pucca houses were destroyed, with 563 severely damaged. On top of that, 40,698 native huts were completely levelled. Reports from the ship Clarence also provided some of the details. ${ }^{61}$ A scheme was being mooted to develop another port as an auxiliary to Calcutta, a place about 45 kilometres to the south-east of Calcutta, deeper in the Ganga-Brahmaputra delta, on the estuarine river, the Matlah. Piddington wrote to the Governor-General of India in 1853, warning the site would be extremely vulnerable to storm surges. Port Canning was commissioned in 1864, and in 1867, a storm of quite moderate intensity brought in six feet (1.8 metres) of water over the settlement. The damaged port was abandoned four years later. Port Canning was an ambitious venture that the government had taken up in Bengal, and this proposal had the approval from the apex office of the colonial administration. Since 1853, the government had undertaken the survey of the lands around river Matlah with the intention of building a subsidiary port to Kolkata and settling a municipality town as well. Work of survey, settlement and formation of a company occurred in rapid succession. That very year, Henry Piddington who had moved his residence in Kolkata to pursue his varied intellectual interests wrote to the GovernorGeneral of India stating that the river Matlah as per his calculations was directly in the way of cyclones a term that he had coined for the sea storms and gales that he had been studying for a while now. His letter was received, and his proposition was reviewed in The Calcutta Review in which his reputation was commended, but his proposal was refuted on the premise that there were no 
facts to support his projection. His critics chose to ignore his warning and stated that given an upsurge in the river one could always resort to the good old system of embankments. The example of prosperous coastal ports and port towns in Europe was thrown in comparison for good measure.

In 1867, Piddington's claim turned out to be true. Port Canning after its grand inauguration in 1864 came in the way of a cyclone and was completely destroyed, never to be rebuilt again. This was one of factors that eventually shelved the proposal drawn up by Ferdinand Schiller. The state had ignored the warnings of experts like Piddington at its own expense. The Sundarbans, however, continued being reclaimed and populated and by the beginning of the 20th century had begun to be reclaimed in its lower reaches within the lease undertaken by Daniel Hamilton who introduced a cooperative system to communally maintain the embankments while he provided its financial cost.

During the long 19th century in the Sundarbans, the colonial state had to contend with floods and cyclones while trying to turn the Sundarbans into a productive geography. At the official level, in the responses from "above" embankments appear to be the answer to all calamities from water. The cyclones of 1864 and 1867 did not seem to have acted as any deterrent or any reference point for reflection as we can see the haste with which Port Canning was constructed despite advice from Henry Piddington. The pertinent question that appears to have engaged them was who would bear the incidence of maintaining and repairing the embankments?

\section{Making the margin from the normal: concluding remarks}

Environmental histories on Kutch and the Sundarbans, especially in terms of the colonial record, suggest that these environments were considered to be dynamic, unpredictable and subject to debilitating impacts from extreme natural events. For the colonial officials and the state consequently, both Kutch and the Sundarbans were considered and treated as marginal environments and, therefore, subjected to different regimes for monitoring and exploitation. Local communities, however, despite many of their vulnerabilities as subsistence cultivators and pastoralists turned mobility and a portfolio of livelihood generating capacities into adaptation strategies rather than simply as coping responses. For the Sundarbans, this disjuncture of responses from "above" and "below" give us insights into the ways in which these continue to be part and parcel of the nature of governance and local-level responses in the postcolonial period. Following the most recent cyclones in the region in the 21st century, Aaila, Titli and Amphan while communities have responded by migration, their options now are much more limited (see Chapter 5). In Kutch, similarly, the responses of the state to frequent droughts and the 2001 earthquake has not brought solace to communities whose water resources are being ever more reduced by dams upriver, water grabbing by the industries and increasing rainfall variability (see Chapter 4). Today in the Banni, the degradation of the grassland has been also 
partly due to the introduction of an alien species by the state, Prosopis juliflora. Nearly, 55\% of the area is today invaded by Prosopis, a leguminous shrub, locally called gandobaval, imported from South America in the 1960s, in an attempt to keep desertification and salinisation at bay. The fragile eco-system of the Kutch is teetering on the edge of an environmental crisis.

Notions about uncertainty, as pointed out earlier, are critically informed by ideas about environmental change (Bennett 2010; Marris 2011;. Environmental histories, on the other hand, can help explore the layered social, economic and political responses to environmental shocks. Consequently, as out study shows, the colonial record on Kutch and the Sundarbans becomes particularly compelling in terms of how subsistence cultures by local communities can offer insights for assembling adaptation strategies in conditions of extreme environmental stress.

\section{Notes}

1 James Macmurdo quoted in Chhaya Goswami, 2011, The Call of the Seas, Kachchhi Traders in Muscat and Zanzibar, 1800-1880, 16: New Delhi Orient Black Swan.

2 James Macmurdo to William Erskine, Esq. \& C. Bombay Feb 1824, Papers Relating to the Earthquake Which Occurred in India in 1819, in The Transactions of the Literary Society of Bombay, 63 (310) Feb, 1824, 105-119.

3 Burnes, A Sketch of the History of Cutch, Bombay, 1830.

4 Alexander Burnes, Memoir on the Eastern Branch of the River Indus, giving and Account of the Alterations produced on it by an Earthquake, also a Theory of the formation of the Runn, and some Conjectures on the Route of Alexander the Great; drawn up in the years 1827-1828 in Transactions of the Royal Asiatic Society of Great Britain and Ireland, 3 (3) (1834), p. 569.

5 Marianna Postans. Cutch or Random Sketches of Western India interspersed with Legends and Traditions, London, 1839.

6 Lieutenant S. N. Raikes, Memoir on the Kutch State, submitted to the Government of Bombay in November, 1854, in Selections from the Records of Bombay Government No. XXVII - New Series, National Archives of India (hereafter NAI), New Delhi.

7 S. N. Raikes, Memoir on the Kutch State, Submitted to Government, November, 1854, NAI, pp. $4-5$.

8 James Burnes in A Sketch of the History of Cutch, Bombay, 1830, p. 30.

9 S. N. Raikes, Memoir on the Kutch State, Submitted to Government, November, 1854, NAI, p. 5.

10 Ibid., p. 84.

11 Ibid., pp. 78-80.

12 Letter from Major H.N. Reeves, Political Agent, Cutch, to C. Gonne, Esquire, Secretary to Government, Political Department, Bombay, No. 123, dated Bhuj, 30th July 1878 , p. 3.

13 S. N. Raikes, Memoir on the Kutch State, Submitted to Government, November, 1854, NAI, p. 84.

14 Ibid., pp. 70-72.

15 Ibid., pp. 69-70.

16 The Kori was the currency of Kutch State until 1948. It was subdivided into 24 Dokda (singular Dokdo), each of 2 Trambiyo. Only coins were issued. Other copper coins in use were called Dhabbu and Dhinglo. The Kori was replaced by the Indian rupee. 1 Kori $=2$ Adhio $=4$ Payalo $=8$ Dhabu $=16$ Dhingla $=24$ Dokda $=48$ Trambiya $=$ 96 Babukiya. 
17 Arthur Malet, Statement Containing Information Relative to the Names of the Towns and Villages in the Province of Kutch; Their Estimated Annual Revenue, and the Names of Their Respective Owners, Submitted to Government on the 1st November, 1842, NAI, pp. $12-13$.

18 In December 1819, 250 Kosias came to Banni carrying of 300-400 cattle. At that time, population combined and soldiers at the outpost combined to reclaim cattle and fight the plunderers as documented in S N Raikes, Memoir on the Kutch State, Submitted to Government, November, 1854, NAI, pp. 47-48.

19 Gazetteer of Bombay Presidency, Vol. 5, Kutch, Palanpur \& Mahikanta, 1880, p. 80, NAI, New Delhi.

20 Gazetteer of Bombay Presidency, Vol. 5, Kutch, Palanpur\&Mahikanta, 1880, p. 120, NAI, New Delhi.

21 Gazetteer of Bombay Presidency, Vol. V, 1880, NAI, pp. 17, 18, 107, 108, 155, $173-$ 176, 207-208.

22 Arthur Malet, Statement Containing Information Relative to the Names of the Towns and Villages in the Province of Kutch; Their Estimated Annual Revenue, and the Names of Their Respective Owners, Submitted to Government on the 1st November, 1842, NAI, pp. $58-59$.

23 Letter from Lieutenant Colonel S.C. LAW, Acting Political Agent, Kutch. To C. Gonne, Esq, Secretary to Government, Bombay. No. 40 of 1872, Camp Mandavi, 4th April 1872, p. 1. - Note: Cost of low rainfall measured in agricultural and revenue losses.

24 Letter from Captain G. R. Goodfellow, Acting Political Agent, Kutch. To C. Gonne, Esq, Secretary to Government, Bombay. No. 75 of 187, Bhuj, 15th June 1873 , p. 1.

25 Letter from Colonel W.C. Parr, Political Agent, Cutch, to C. Gonne, Esquire, Secretary to Government, Political Department, Bombay, No. 93 of 1876, dated Bhuj, 20th June 1876, p. 6.

26 Report on the Administration of the Cutch State for 1891-1892, p. 21 Bhuj, 'Cutch Darbari' Press. 1892. Note: Clear suggestion of nomadic patterns.

27 Report on the Administration of the Cutch State for 1891-1892. Bhuj, 'Cutch Darbari' Press. 1893, p. 25.

28 Report on the Administration of the Cutch State for 1885-1886. Bombay: Printed at the Bombay Gazette Steam Press, Rampart Row. 1886, p. 18.

29 Letter from Major H.N. Reeves, Political Agent, Cutch, to C. Gonne, Esquire, Secretary to Government, Bombay, No. 73 of 1880, Political Department Bhuj, 12th July 1880 , p. 6.

30 Report on the Administration of the Cutch State for 1885-1886. Bombay: Printed at the Bombay Gazette Steam Press, Rampart Row. 1886, p. 18.

31 Report on the Administration of the Cutch State for 1885-1886. Bombay: Printed at the Bombay Gazette Steam Press, Rampart Row. 1886, p. 19. - Note: Policy intervention to increase cultivation.

32 Bengal District Gazetteers: Khulna. L.S.S. O'Malley, Indian Civil Service. Calcutta: The Bengal Secretariat Book Depot. 1908, p. 23. Note: First mention of fishing as possibly being a lucrative activity.

33 Frederick E. Pargiter, A Revenue History of the Sundarbans, 1765-1870, 1885, Bengal Government Press, 1934-1935, Chapter 1, pp. 1-9. Available at http://www. southasiaarchive.com/Content/sarf.140487/201193/001 (accessed on 2 January 2020).

34 F. E. Pargiter, A Revenue History of Sundarbans, 1765-1870, Chapter 24, pp. 109-110.

35 F.D. Ascoli, A Revenue History of the Sundarbans from 1870 to 1920, Secretary to the Board of Revenue. Calcutta: Bengal Secretariat Book Department, 1921, p. 15.

36 Report of the Administration of Bengal (1871-1872). Calcutta, Bengal Secretariat Press. 1873, p. 145. Notes: Describes Sunderbans as supplying key resources to Bengal. 
37 Report of the Administration of Bengal (1887-1888). Calcutta, Bengal Secretariat Press. 1889 , p. 20.

38 Report of the Administration of Bengal (1905-1906). Calcutta, Bengal Secretariat Book Depot. 1907, p. 20.

39 The Imperial Gazetteer of India. Volume 23. Meyer, William Stevenson, Sir, 1860-1922. Burn, Richard, Sir, 1871-1947. Cotton, James Sutherland, 1847-1918. New edition, published under the authority of His Majesty's secretary of state for India in council. Oxford, Clarendon Press, 1908-1931 [v. 1, 1909] Sir Herbert Hope, 1851-1911. p. 143.

40 F.D. Ascoli, A Revenue History of the Sundarbans from 1870 to 1920, Secretary to the Board of Revenue, Calcutta, Bengal Secretariat Book Department. 1921, p. 15. Notes: Disputed nature of distinguishing between valuable forest lands to be preserved versus wastelands to be brought under cultivation.

41 Ibid.

42 Letter from S C Bayley, Esquire, Junior Secretary to the Government of Bengal, to the Secretary to the Board of Revenue, Lower Provinces, 30 January, 1865, No. 396, NAI, New Delhi.

43 Proceedings of the Asiatic Society of Bengal Edited by the General Secretary, January to December 1868, Calcutta: Printed by C.B. Lewis, Baptist Mission Press, p. 265.

44 Proceedings of the Asiatic Society of Bengal Edited by the General Secretary, January to December 1868, Calcutta: Printed by C.B. Lewis, Baptist Mission Press, pp. 266-267. Please note, Talar means an erected platform near temples and palaces for musicians.

45

45 L.S.S. O'Malley, Bengal District Gazetteers: Khulna, Calcutta: The Bengal Secretariat Book Depot. 1908, p. 107.

46 Ibid., 107

47 F.D. Ascoli, A Revenue History of the Sundarbans from 1870 to 1920, Secretary to the Board of Revenue, Calcutta, Bengal Secretariat Book Department, 1921, p. 66. Note: Cyclone of 1878 documented. Gazetteer of Bakarganj District 1918.

48 Ibid., p. 66.

49 Ibid.

50 Ibid., p. 71.

51 L.S.S. O'Malley, Bengal District Gazetteers, Khulna, Calcutta: The Bengal Secretariat Book Depot. 1908, p. 20. Notes: Practices around cutting wood and tigers are discussed extensively.

52 Report of the Administration of Bengal (1914-1915). Calcutta: The Bengal Secretariat Book Depot. 1916, p. 67. Notes: The trajectory of how the large number of people being killed by tigers in the Sundarbans declines as the number of tiger killings increases.

53 Report of the Administration of Bengal (1915-1916). Calcutta: The Bengal Secretariat, Book Depot. 1917, p. 66.

54 The world's biggest weather phenomena are: The Pacific Ocean, the monsoon, the atmosphere, the seasons.

55 Henry Piddington, Law of Storms in India, (An Eighteenth Memoir on the) being the Cyclone of the 12th to 14th Oct. 1848, in the Bay of Bengal, Journal of the Asiatic Society of Bengal, Vol. XVIII, Part II,-July to December 1849, pp. 826-869.

56 Lieut. Col. J. E. Gastrell and Henry F. Blanford, A.R.S.M, 'Report on the Calcutta Cyclone of the 5th October 1864, with Maps and Diagrams Illustrating the Origin and Progress of the Storm and the Track of the Storm Wave. Calcutta, O.T. Cutter, Military Orphan Press, 1866.

57 Blanford, 1864 Calcutta Cyclone, pp. 110-112.

58 Blanford, 1864 Calcutta Cyclone, p. 56.

59 India: The Cyclone at Calcutta, account printed in The Calcutta Englishman, October, 10 reprinted in General News column in New York Times, November 24, 1864, https://www.nytimes.com/1864/11/24/archives/general-news-india-the-cycloneat-calcutta.html last accessed on 20 December, 2019. 
60 Ship log of Clarence kept by James Watson, 1858-1873, MSS Coll 832, University of Pennsylvania.

61 Henry Piddington, 'On the Cyclone Waves in the Soonderbuns - A Letter to the Most Noble the Governor-General of India' 1853. Calcutta Review, Vol. XXIV, January to June, 1855 , pp. 330-342.

\section{References}

Ascoli, F.D. 1921. A Revenue History of the Sundarbans from 1870 to 1920. London: Routledge.

Asiatic Society of Bengal. 1849. Journal of the Asiatic Society of Bengal Vol. XVIII, Part II, July to December 1849. Kolkata: The Asiatic Society of Bengal.

Bengal Government. 1865. Board of Revenue Proceedings Records Room. New Delhi: Records Room of the National Archives of India.

Bennett, J. 2010. Vibrant Matter: A Political Ecology of Things. Durham, NC: Duke University Press.

Bhattacharya, N. 2018. The Great Agrarian Conquest: The Colonial Reshaping of a Rural World. Ranikhet: Permanent Black.

Burnes, J. 1830a. A Narrative of a Visit to the Court of Sinde; A Sketch of the History of Cutch, from Its First Connexion with the British Government in India till the Conclusion of the Treaty of 1819; and Some Remarks on the Medical Topography of Bhooj. Edinburgh: John Stark 1831 at Asia Pacific \& Africa Collection, British Library, UK.

Burnes, J. 1830b. A Sketch of the History of Cutch. New Delhi: Asian Educational Services. Accessed via PragMahal Archives, Bhuj, Gujarat.

D'Souza, R. 2019. 'Scarcity, Environmentalism and the Politics of Pre-Emption: Reconsidering the Environmental Histories of South Asia in the Epoch of the Anthropocene'.Geoforum, 101: 242-249. https://doi.org/10.1016/j. geoforum.2018.09.033

Damodaran, V. and R. D'Souza, eds. 2020. Commonwealth Forestry and Environmental History: Empire Forests and Colonial Environments in Africa, the Caribbean, South Asia and New Zealand. New Delhi: Primus Books.

Gastrell, Lieut. Col., J. E. and H.F. Blanford. 1866. Report on the Calcutta Cyclone of the 5th October 1864, with Maps and Diagrams Illustrating the Origin and Progress of the Storm and the Track of the Storm Wave. Calcutta: O.T Cutter, Military Orphan Press.

Gazetteer of the Bombay Presidency. 1880. Volume V, Cutch, Palanpur, and Mahikanta. Bombay: Government Central Press. Accessed via the National Archives of India, Library, New Delhi.

Grove, R., V. Damodaran, and S. Sangwan. 1998. Nature and the Orient: The Environmental History of South and Southeast Asia. New Delhi: Oxford University Press.

Heredia, R.C. and S.F. Ratnagar, eds. 2003. Mobile and Marginalized Peoples: Perspectives from the Past. New Delhi: Manohar.

Ibrahim F. 2004. 'No place like home, History, politics and mobility among a pastoral nomadic community in Western India'. Nomadic Peoples, New Series, Special Issue: Whither South Asian Pastoralism? 8(2): 168-190.

Jasanoff, S. 2010. 'A New Climate for Society'. Theory, Culture \& Society, 27(2-3): 233253. https://doi.org/10.1177/0263276409361497

Jasanoff, S. and M.L. Martello, eds. 2004. Earthly Politics: Local and Global in Environmental Governance. Cambridge, MA: MIT Press.

Journal of the Asiatic Society of Bengal, Vol. XVIII, Part II,-July to December. 1849. Accessed via The Asiatic Society Library, Kolkata. 
Kumar, D., V. Damodaran, and R. D'Souza, eds. 2011. The British Empire and the Natural World: Environmental Encounters in South Asia. New Delhi: Oxford University Press.

Lieutenant, A. 1834. 'Memoir on the Eastern Branch of the River Indus, Giving an Account of the Alterations Produced on It by an Earthquake, Also a Theory of the Formation of the Runn, and Some Conjectures on the Route of Alexander the Great; Drawn up in the Years 1827-1828'. Transactions of the Royal Asiatic Society of Great Britain and Ireland, 3(3): 550-588. Available here: https://www.jstor.org/ stable/25581779?seq=1\#metadata_info_tab_contents (Accessed 15 August 2018).

Malet, A. 1842. Statement Containing Information Relative to the Names of the Towns and Villages in the Province of Kutch; Their Estimated Annual Revenue, and the Names of their Respective Owners. Accessed via the National Archives of India, New Delhi.

Malley, L.S.S.O. 1908. Bengal District Gazetteers, Khulna. Calcutta: The Bengal Secretariat. Accessed via the Diectorate of State Archives, Kolkata, West Bengal.

Marriss, E. 2011. The Rambunctious Garden: Saving Nature in a Post-Wild World. Bloomsbury.

Mehta, L. 2005. The Politics and Poetics of Water: The Naturalization of Scarcity in Western India. Hyderabad: Orient Blackswan.

New York Times. 1864. 'General News Column'. The New York Times, New York, November 24.

Pargiter, E.F. 1885. A Revenue History of the Sundarbans, 1765-1870. Kolkata: Bengal Government Press. Available at: http://www.southasiaarchive.com/Content/ sarf.140487/201193/001 (Accessed 20 December 2019).

Postans, M. 1839. Cutch or Random Sketches of Western India Interspersed with Legends and Traditions. Kachchh: Smith, Elder and Company. Accessed via London, Library and The Asiatic Society, Mumbai.

Prasad, A. 2003. Against Ecological Romanticism: Verrier Elwin and the Making of an AntiModern Tribal Identity. New Delhi: Three Essays Collective.

Proceedings of the Asiatic Society of Bengal, January to December 1868. 1868. Calcutta: C.B. Lewis, Baptist Mission Press. Accessed via the Asiatic Society Library, Kolkata.

Raikes, S.N. 1854. Memoir of the Kutch State. Submitted to Government, New Delhi. Accessed via the National Archives of India, New Delhi.

Rennell, J. 1794. 'A Map of the North Part of Hindostan or a Geographical Survey of the Provinces of Bengal, Bahar, Awd, Ellahabad, Agra and Delhi'. Available at: https:// apps.lib.umich.edu/online-exhibits/exhibits/show/india-maps/item/5156 (Accessed on 28 July 2021).

Report of the Administration of Bengal 1871-1872. 1872. Calcutta: Bengal Secretariat Press. Accessed via the Directorate of State Archives, Kolkata, West Bengal.

Report of the Administration of Bengal 1887-1888. 1888. Calcutta: Bengal Secretariat Press. Accessed via the Directorate of State Archives, Kolkata, West Bengal.

Report of the Administration of Bengal 1905-1906. 1907. Calcutta: The Bengal Secretariat Book Deposit. Accessed via the Directorate of State Archives, Kolkata, West Bengal. Report of the Administration of Bengal 1914-1915. 1916. Calcutta: Bengal Secretariat Book Deposit. Accessed via the Directorate of State Archives, Kolkata, West Bengal.

Report of the Administration of Bengal 1915-1916. 1917. Calcutta: Bengal Secretariat Book Deposit. Accessed via the Directorate of State Archives, Kolkata, West Bengal.

Report of the Administration of Cutch State for 1871-1872; 1875-1876; 1877-1878; 18791880; 1885-1886; 1891-1892. Accessed via the British Library, India Office Records, Asia, Pacific \& Africa Collection, UK.

Saikia, A. 2019. The Unquiet River: A Biography of the Brahmaputra. Oxford: Oxford University Press. 
82 Vinita Damodaran et al.

Simpson, E. 2003. 'Migration and Islamic Reform in a Port Town in Western India'. Contributions to Indian Sociology, 37(1-2): 83-108. https://doi.org/10.1177/0069966 70303700105

STSC 077. 2015. 'Sailing the British Empire: The Voyages of The Clarence, 1858-73'. Seminar by STSC 077, University of Pennsylvania, USA.

The Calcutta Englishman. 1864. 'India: The Cyclone at Calcutta'. The Calcutta Englishman. Calcutta, 10 October.

The Calcutta Review, Vol. XXIV, January to June, 1855. 1855. Calcutta: Sanders, Cones and Co. Accessed via the University Library, University of Calcutta.

The Imperial Gazetteer of India, Vol. XXIII Singhbhum to Trashi-Chod-Zong. 1909. Oxford: Clarendon Press. Available at: https://dsal.uchicago.edu/reference/gazetteer/ (Accessed on 10 January 2019).

Transactions of the Literary Society of Bombay. 1824. Mumbai: Asiatic Society of Bombay. 